\title{
CLASSIFICATION OF THE FOSSORIAL, PREDACEOUS AND PARASITIC WASPS, OR THE SUPERFAMILY VESPOIDEA.
}

BY WILliam H. ASHMEAD, A. M., ASSISTANT CURATOR, DIVISION OF INSECTS, U. S. NATIONAL MUSEUM.

(Paper No. 13.-Continued from Vol. XXXV., p. 44.)

FAMILY XL.-Thynnidæ.

This family, although quite distinct, is closely allied to the two which follow-the Myrmosidee and the Mutillide-and it will probably be difficult for the student to separate at once the wingless females from some in the families mentioned. Some authorities, having been unable to find good characters to separate these wasps, have classified all together as a single large family under the name Mutillidce; but I think incorrectly so.

The middle coxæ are not contiguous, as in the Mutillide and Myrmosida, being separated, usually, by a triangular or bilobed projection of the mesosternum, while the thorax in the females is also quite distinct, being divided into three parts; in the Myrmoside the thorax is divided into two parts only, while in the Mutillide it is undivided, the pro-, mesoand meta-thorax being closely united, without distinct dividing sutures.

The males in the three families, to a certain extent, closely resemble one another, and are not so easily separated, although each family has a distinct habitus peculiarly its own, which one easily recognizes with practice, the shape of the head, the thorax and the abdomen being slightly different; the genitalia armature, however, with but few exceptions, is quite different in the three families.

Many genera have been proposed for these wasps, the majority of which I consider good, although Dr. von Dalla Torre, in his Catalogus Hymenopterorum, has placed most of them under the genus Thynnus, Fabr., causing much confusion. This arrangement throws a great many with the same specific name together, and for these he has proposed new specific names, which still further complicates matters, burdens our literature with names that will not hold, but which must be quoted, and making it exceedingly difficult to keep track of.

I find the date of Guérin's Paper on this group, published in Duprerry's Voyage de la Coquille, is given as i 830 , whereas, although the title page is so dated, it did not appear until 1839 ; it also makes certain changes in synonymy necessary. 
The family is very large and widely distributed, but is more extensively represented in South America, in Australia and Africa than elsewhere, Europe and North America having only á few representatives.

The study of the genera and species is most difficult on account of the great dissimilarity of the sexes, the slowness with which material comes in, and the absence of good collectors to take the sexes in coitu, so that the sexes can be correctly correlated and the genera more thoroughly elaborated.

I have divided the family into three subfamilies, which may be recognized by the characters employed in the following table:

Table of Subfamilies.

Females

Males.

I. Body rather short, not elongate: thorax above convex, the metathorax very short, obliquely truncate posteriorly, transversely compressed or sublamellar, more rarely long $\ldots \ldots \ldots \ldots \ldots \ldots \ldots \ldots \ldots \ldots \ldots \ldots \ldots \ldots \ldots$ Body elongate and slender; thorax above more or less flattened, rarely convex.

Metathorax never very short, nor transversely compressed; abdomen smooth, the second dorsal segment without transverse folds or carinæ, the pygidium and hypopygium normal....2.

Metathorax very short, obliquely truncate posteriorly, from the base or very near the base, transversely compressed or sublamellar; abdomen not smooth, variously sculptured, the second dorsal segment more or less punctured, or rugulose, and usually with two or more transverse folds or carinæ, sometimes many ; pygidium and hypopygium abnormal, variously modified ............... Subfamily I., Thynninæ.

2. Head transverse, much wider than long, the eyes large, the ocelli distinct................. Subfamily II., Methocinæ.

Head large, oblong, quadrate or nearly, more rarely subrotund or obtrapezoidal, the eyes not large, the ocelli usually

wanting $\ldots \ldots \ldots \ldots \ldots \ldots$ Subfamily III., Rhagigasterinæ.

3. Metathorax short, usualiy obliquely truncate from its base; abdomen not wholly smooth, the second dorsal segment punctate or rugulose, and usually with two or more transverse folds or carinæ, the pygidium and hypopygium abnormal, variously modified, the latter usually 
dilated into a broad margin at apex, or trumpet-shaped, the former often striate or coarsely sculptured ....... Stibfamily I., Thynninæ. Metathorax not very short; abdomen smooth, the second dorsal segment without transverse folds or carinæ, the pygidium and hypopygium normal, not modified in any

way ................

4. Hypopygium armed with one or more spines or teeth or trilobed . .5. Hypopygium unarmed, at apex truncate or rounded..........

5. Thorax elongate; front wings with radial and cubital cells . . . . .6. Thorax rounded; front wings without radial and cubital cells . . . . 9.

6. First transverse cubitus distinct, with an appendage $\ldots \ldots \ldots \ldots 7$. First transverse cubitus wanting, or if present, without an appendage..8.

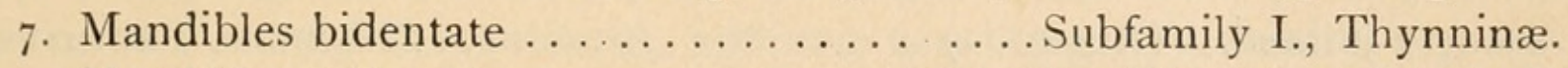
Mandibles tridentate ........... Subfamily III., Rhagigasterinæ.

8. Hypopygium produced at apex into a long aculeus which curves upwards................... Subfamily II., Methocinæ. Hypopygium armed with a long aculeus which curves upwards, but that originates before the apex.... . Subfamily III., Rhagigasterinæ.

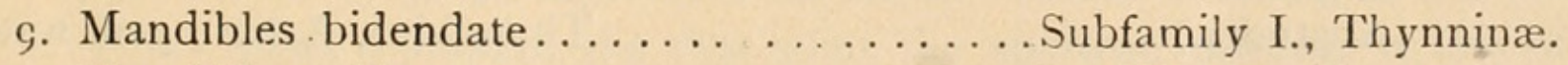
Mandibles tridentate ........... Subfamily III., Rhagigasterinæ.

Subfamily I.-Thynninæ.

The males in this group show a wonderful difference in the structure of the mouth-parts and in their genitalia, which, in time, will enable the group to be divided into four or more tribes, namely, Thynnini, Myrmecodini, Scotaenini, Amblysomini, etc.; but this had better not be done until more of the forms, in both sexes, are known.

Males

Table of Genera.

Females

I. Hypopygium armed, ending in a single triangular tooth or spine, or tridentate or trilobed; sometimes 5 -dentate, a small tooth on each side at base in addition to the apical teeth; sometimes oblong, narrowed, tridentate, or trilobed at apex...............

Hypopygium unarmed, truncate or rounded at apex ........

2. Hypopygium at least tridentate or trilobed, sometimes 5 -dentate $\cdots 3$. Hypopygium ending in a large triangular tooth or single spine, rarely with indications of a lobe at the basal angles of same, the lateral margins sometimes arcuate or rounded 
3. Hypopygium 3-dentate, or trilobed $\ldots \ldots \ldots \ldots \ldots \ldots \ldots \ldots \ldots \ldots \ldots \ldots$. Hypopygium 5 -dentate, or with 5 spines.

Clypeus produced and anteriorly truncate or subarcuate, with a short, stout tooth or elevation at the basal lateral angles, near the base of the eyes.....................

Clypeus anteriorly not much produced, rounded, without a tooth at the basal lateral angles...............

4. Abdomen fusiform or ovate, not longer than the head and thorax united, the segments constricted at the sutures; segments $2-3$, or more, with yellow or yellowish-white spots; first ventral segment with a triangular tooth or elevation near the middle, the sixth with a tooth at the apical angle; maxillary palpi 6-jointed; labial palpi 4-jointed. (Australia)................ Thynnus, Fabricius.

(Type T. dentatus, Fabr.)

Abdomen longer than the head and thorax united, the sides nearly parallel, the segments more or less constricted at the sutures, black, immaculate, the first and sixth ventral segments normal, unarmed ; maxillary palpi 6-jointed, the joints short; labial palpi 4-jointed. (Australia.) . . . . . . . . . . . . . Thynnidea, Ashm., gen. nov.

(Type Thynnus fumipennis, Westw.)

5. Metathorax with a median tooth at apex; abdomen longer than the head and thorax united, cylindrical, the sides parallel, the segments constricted at apex, immaculate; maxillary and labial palpi both 4-jointed. (Australia).............. Iswaroides, Ashmead. (Type I. Koebelei, Ashm.)

6. Marginal cell at apex pointed or slightly rounded, but never truncate; second cubital cell not triangular................ Marginal cell at apex truncate; second cubital cell triangular.

Clypeus with a median emargination anteriorly; maxillary and labial palpi both 3-jointed. (India) ...... Iswara, Westwood.

(Type I. luteus, Westw.)

7. Hypopygium not narrow, in outline triangular, 3 -dentate, the middle tooth large, triangular, projecting far beyond the lateral teeth, which are usually small $\ldots \ldots \ldots \ldots \ldots \ldots \ldots \ldots \ldots \ldots \ldots \ldots \ldots \ldots \ldots \ldots \ldots \ldots \ldots$.

Hypopygium quite differently shaped, narrower and oblong, as wide or nearly at apex as at base, the sides parallel or nearly, the apex usually briefly tridentate or trilobed, the teeth or lobes equal or nearly, the middle tooth very rarely much longer than the lateral

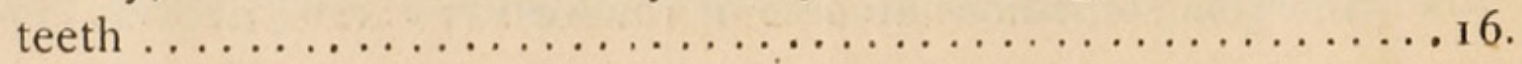


8. Clypeus produced anteriorly and entirely covering the labrum, or the latter only slightly visible $\ldots \ldots \ldots \ldots \ldots \ldots \ldots \ldots \ldots \ldots \ldots \ldots \ldots \ldots \ldots$.

Clypeus not so produced, the disk thickened, convex, the labrum usually large and distinctly visible, rarely partly concealed.

Head with a prominence above the insertion of the antennæ and connected with the clypeus by a carina; antennæ of moderate length ; fifth ventral segment with a tooth at each apical angle; pygidium subtriangular, broader at base than long, and longitudinally striated; maxillary palpi 6-jointed; labial palpi 4-jointed. (Australia)......Zaspilothynnus, Ashm., gen. nov. (Type Thynnus Leachiellus, Westw.)

Head anteriorly with two prominences, beneath which are inserted the antennæ; antennæ very long; fifth ventral segment without a tooth at the apical angles.

(Australia) ................ Tachynomyia, Guérin.

('Type Agriomyia spinolæ, Guér.)

9. Clypeus trapezoidal, truncate anteriorly.

Maxillary palpi 6-jointed, the middie joints the longest; labial palpi 4 -jointed, the first joint the shortest, without a tuft of hairs at apex, joints $2-4$ longer, nearly equal in length. (Australia) ............. Thynnoides, Guérin.

(Type T. fulvipes, Guér.)

Maxillary palpi 6-jointed, the three last joints very long, much longer and slenderer than the basal joints; labial palpi 4-jointed, the first very long, nearly as long as joints $2-4$ united, with a tuft of very long hairs at

apex. (Australia).......... Pseudaelurus, Ashm., gen. nov.

(Type Aelurus abdominalis, Guérin.)

I o. Clypeus anteriorly truncate or very slightly arcuate, never emarginate; pygidium neither carinate at sides nor truncate at apex....... I I. Clypeus anteriorly broadly, shallowly semicircularly emarginate, concave or excised; pygidium squarely truncate at apex and usually carinate at sides, the apical lateral angles acute.......... I $_{5}$.

I I. Pygidium at apex rounded, without a median incision or emargina-

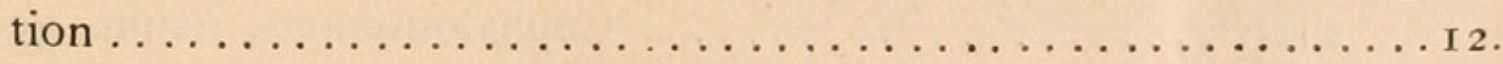

Pygidium at apex rounded, but with a median incision or emargination. Abdomen fusiform, maculate; hypopygium with the sides strongly rounded or arcuate, and ending in a rather long spine, which is 
more than three times as long as thick at base; maxillary palpi 6-jointed ; labial palpi 4 -jointed.

(Australia) .................. Catocheilus, Guérin.

(Type C. Klugii, Guér.)

12. Clypeus produced anteriorly, trapezoidal, the front margin squarely truncate and overlapping the mandibles, the labrum invisible; abdomen not smooth, more or less punctate............ I3.

Clypeus very similar but not so much produced anteriorly, the mandibles wholly exposed, the labrum more or less visible; abdomen smooth, shining, or at most with fine, microscopic lines.

Labrum narrowly transverse or arcuate, not bilobed; hypopygium ending in an acute spine, the lateral margins slightly arcuate, the basal angles with usually a slight lobe, but not acute enough to be considered a tooth; mandibles bidentate, the outer tooth the longer and larger; maxillary palpi 6-jointed, the three last joints much slenderer than the preceding joints, the last joint not longer than the penultimate; labial palpi 4 -jointed . . . . . . . . . . . Myrmecodes, Latreille.

(Type Tiphia pedestris, Fabr.)

Labrum bilobed; hypopygium ending in a spine which curves slightly upwards, the lateral marginz almost straight.

Maxillary palpi 6-jointed, the last joint longer than the penultimate ; labial palpi 4 -jointed.

(Australia) .............Guérinius, Ashm., gen. nov.

(Type Thynnus flavilabris, Guér.)

I3. First ventral segment unarmed .................. I4.

First ventral segment armed with a prominent median tooth.

Head more than twice as wide as thick antero-posteriorly; abdomen maculate ; maxillary palpi

6-jointed .................. Agriomyia, Guérin.

(Type A. maculata, Guérin.)

I 4. Abdomen ovate, maculate, the hypopygium oval, ending in a short spine; maxillary palpi 6-jointed, the three last joints longer than the first three; labial palpi 4 -jointed, the joints

short ............. Cephalothynnus, Ashm., gen. nov, (Type Thynnus odyneroides, Westw.)

Abdomen fusiform, longer than the head and thorax united, the hypopygium triangularly pointed, the sides only slightly arcuate; 
maxillary palpi 6-jointed, the second and the last joint longer than joints $3-5$; labial palpi 4 -jointed,

short ................ Hemithynnus, Ashm., gen. nov.

(Type Thynnus hyalinatus, Westw.)

15. Maxillary palpi 6-jointed, long, the joints, except the first, which is very short, long, subequal, the last joint the slenderest and a littie the longest; labial palpi 5-jointed. (South

America) .................. Elaphroptera, Guérin.

(Type Myrmecodes dimidiatus, Hal.

16. Hypopygium ending in three smali, equal or nearly equal, triangular teeth, rarely with the middle tooth much longer than the lateral, or spined .........................

Hypopygium ending in three small, equal, rounded lobes....... 9 .

1 7. Clypeus subproduced and anteriorly emarginate, excised or

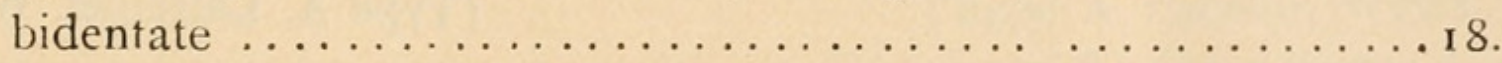

Clypeus produced, trapezoidal, the anterior margin truncate, never emarginate or excised.

Abdomen elongate, subcylindrical, smooth, shining, spotted with yellow, much longer than the head and thorax united; first joint of flagellum only about half the length of the second; hypopygium at apex 3 -spined, the middle spine the longest. (Australia)........Aeolothynnus, Ashm., gen. nov.

(Type A. multiguttatus, Ashm.)

18. Abdomen oblong-oval or fusiform, longer than the head and thorax united, the segments banded or maculate with white or yellow. (South America).... Pseudelaphroptera, Ashm., gen. nov.

(Type Elaphroptera Spinolæ, Sauss.)

I 9. Clypeus broadly, semicircularly emarginate anteriorly, leaving a deep concave space; metathorax with two deep impressions or short furrows at apex; maxillary palpi long, 5-jointed, the first joint short; maxillary palpi 4-jointed; abdomen elongate, narrowed towards base, shining, but microscopically shagreened. (South America)............. Pycnothynnus, Ashm., g. nov.

(Type Elaphroptera atra, Guér.

20. Third cubital cell, along the cubitus, shorter than the second or no

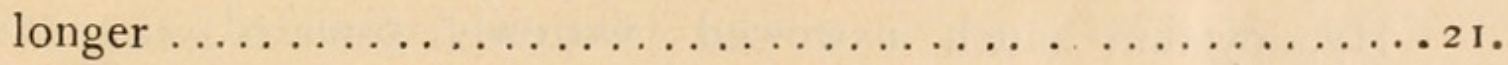

Third cubital cell distinctly longer than the second........ 
2I. Clypeus subproduced, with a slight median sinus or incision anteriorly, the labrum well developed ; maxillary palpi 5 -jointed; labial palpi 4-jointed. (Australia)............... Anthobosca, Guérin. (Type A. Australasiæ, Guér.

22. Mandibles narrower, curved, the teeth acute; abdomen oblong, fusiform or subcylindrical, as long or longer than the head and thorax united $\ldots \ldots \ldots \ldots \ldots \ldots \ldots \ldots \ldots \ldots \ldots \ldots \ldots \ldots \ldots \ldots \ldots \ldots \ldots \ldots \ldots \ldots \ldots \ldots \ldots$

Mandibles broad, the apical tooth large, obtuse, the inner tooth with a long cutting face ; abdomen oval, hardly as long as the thorax or no longer.

Head about twice as wide as thick antero-posteriorly, not wider than the thorax; pronotum short, transverse; mesonotum fully as wide as long, with two furrows; metathorax short, rounded behind................ Amblysoma, Westw.

(Type A. Jatreillei, Westw.)

23. First transverse cubitus with an appendage ........... 24 .

First transverse cubitus without an appendage.

Abdomen long, cylindrical, the first segment much longer than wide at apex, petioliform. (South

America) .............. Klugianus, Ashm, gen. nov.

(Type Thynnus haematodes, Klug.)

24. Clypeus produced and anteriorly broadly truncate, trapezoidal . . 25.

Clypeus anteriorly not broadly truncate, slightly rounded, subemarginate, deeply triangularly emarginate, or bidentate...... 26.

25. Clypeus with a median carina; maxillary palpi 6-jointed, slender; labial palpi 4 -jointed; abdomen maculate or fasciate with yellow. (Australia).................. Zeboria, Saussure.

(Type Thynnus carinatus, Smith.)

Clypeus without a median carina; maxillary palpi 6-jointed, not slender; labial palpi 4-jointed; abdomen with white spots, the hypopygium near the tip with a pointed and a clavate appendage of hairs.............. Psammothynnus, Ashm., gen. nov.

(Type Thynnus depressus, Westw.)

26. Hypopygium not prominently projecting, always obtuse or truncate at

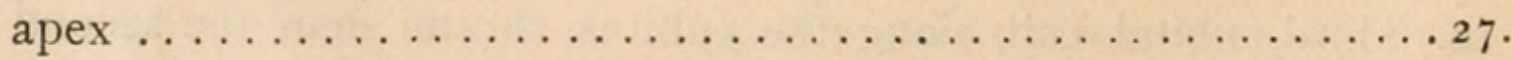

Hypopygium much narrowed, narrowly rounded at apex, and prominently projecting beyond the tip of the abdomen. 
Clypeus anteriorly subtriangularly emarginate or tridentate; maxillary palpi 6 -jointed, the first joint short, the following joints longer, subequal ; labial palpi 4 -jointed, the first joint shorter than the 2 nd and $3^{\text {rd }}$ united; abdomen spotted. (South America) . . . . . . . Spilothynnus, Ashm., gen. nov.

(Type Thynnus laetus, Klug.)

27. Clypeus anteriorly subemarginate, deeply emarginate or

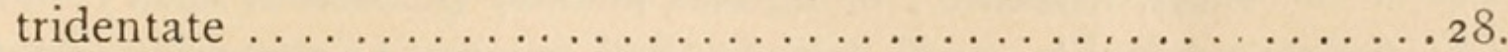

Clypeus anteriorly rounded, not emarginate.

Abdomen fusiform, a little longer than the head and thorax united, maculate or fasciate; maxillary palpi 6-jointed, the last three joints much longer than the first three, or twice as long; labial palpi 4 -jointed, joints $\mathrm{I}$ and 4 longer and slenderer than 2 and 3, which are short, stout. (South

America .

. Anodontyra, Westwood.)

(Type A. tricolor, Westw.)

28. Clypeus anteriorly subemarginate; maxillary palpi 6-jointed, joints $\mathrm{I}-3$ rather short, joints 4-6 long, subequal, five or six times longer than thick ; labial palpi 4 -jointed, the first joint long and slender, about as long as $2-4$ united; abdomen fasciate. (South America.)

Clypeus anteriorly bidentate; maxillary palpi 6-jointed, the joints obconical, unequal, the first four short, the third and fourth much longer than the second. (South America)...... Ornepetes, Guérin.

(Type O. nigriceps, Guér.)

29. Pygidium not very narrow, oblong, rounded at apex, usually shagreened, punctate, rugulose or striate; if smooth, which is rare, it is curiously modified, compressed towards base and broadened into an elevation posteriorly ; basal segment of abdomen without a strongly curved furrow on each side or a strong transverse furrow before the apex.. 30 . Pygidium very narrow, smooth and shining; basal abdominal segment with a strongly curved furrow on each side, or a deep, transverse furrow before apex.

Basal abdominal segment with a strongly curved furrow on each side; second segment with about three transverse folds or carinæ; pygidium with two pencils of long golden hairs that curve and meet above the narrow elevation on its disk...........................

Basal abdominal segment with a strong transverse furrow just before apex; second segment with three transverse folds or 
carinæ; pygidium long, lanceolate, broadest at apex, without the two pencils of golden hairs.......... Thynnidea, Ashm.

30. Head seen from above not triangular, usually transverse, subquadrate or obtrapezoidal. . . . . . . . . Head seen from above triangular.

Eyes small, oval, extending to base of mandibles; clypeus very short, truncate ; mandibles falcate, pointed at apex; maxillary palpi 4-jointed; labial palpi 3-jointed; second segment of abdomen with two transverse folds or carina towards apex.................... Iswaroides, Ashmead.

31. Pronotum not quadrate, obtrapezoidal, or wider in front than behind...33. Pronotum quadrate, usually, however, a little wider than long, but not wider in front than behind.

Head not or scarcely wider than the thorax, the latter not especially narrow . . . . . . . . . .

Head much wider than the thorax, the latter being very narrow, with the sides parallel; dorsal abdominal segments $\mathrm{I}$ and 2 strongly transversely furrowed; pygidium oval or nearly and longitudinally striate............ Catocheilus, Guérin.

32. Clypeus slightly produced, truncate anteriorly, the labrum visible as a narrow transverse line, ciliate; mandibles narrow, acute at apex ; maxilary palpi 6-jointed, not short; labial palpi 4-jointed. (Australia) .. .....................

(Type E. bicolor, Westw.)

Clypeus short, broadly truncate anteriorly, but the labrum not visible ; mandibles falcate, rounded at apex; maxillary and labial palpi both 4-jointed; first abdominal segment with a broad, finely shagreened depression at apex, the second segment with two transverse carinæ, the intermedian space between the carinæ shagreened, opaque; pygidium narrowly compressed towards apex and then abruptly dilated or trumpet-shaped............. Spilothynnus, Ashm.

33. Head large, obtrapezoidal, subquadrate or subglobose, the temples or the space back of the eyes very broad, without furrows or impressions extending from the antennæ to the vertex......... Head transverse, much wider than thick antero-posteriorly, the temples not especially broad, with sometimes two furrows or impressions extending from antennæ to vertex $\ldots \ldots \ldots \ldots \ldots 4$. 
34. Head subquadrate or subglobose. 35 Head large, obtrapezoidal, the temples abnormally broad.

Abdomen oblong oval, the second dorsal segment with three or four transverse folds or carinæ; pygidium long oval, longitudinally striate; labrum longly ciliated; maxillary palpi minute, 2-jointed ; labial palpi 4-jointed, the last joint as long as joints I-3 united. (Australia.). .......... Cephalothynnus, Ashm.

35. Head subquadrate or subglobose, the hind angles rounded, the temples about four times the width of the eye ........... Head almost quadrate, only a little wider than long, the temples only about twice the width of the eye.

Abdomen large, oblong-oval, the second dorsal segment with about five transverse carinæ; pygidium long, ellipzoidal, very slightly narrowed at the middle and longitudinally striate; labrum hardly visible, ciliate; maxillary palpi minute, 2 -jointed; labial palpi short, 3 -jointed, the second joint the longest and thickest.................. (?) Thynnidea, Ashm.

36. Metathorax with the disk of the oblique truncation flat but not

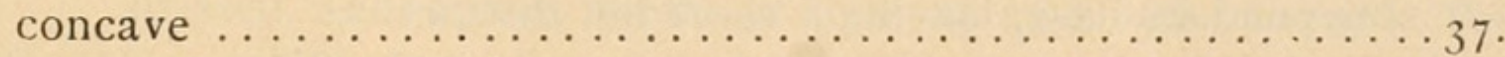

Metathorax with the disk of the oblique truncation concave or subconcave.

Abdomen large, oblong-oval, the second dorsal segment coarsely rugulose, with two transverse folds or carinæ at apex; pygidium longitudinally rugulose ........... Elaphroptera, Guérin.

37. Metathorax without a hump-like elevation at base just behind the

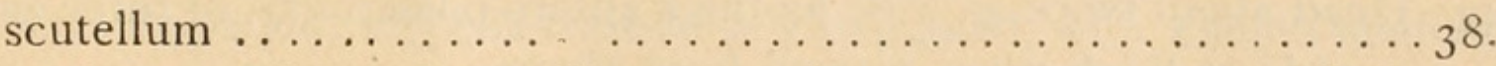

Metathorax with a hump-like elevation at base just behind the scutellum.

Second abdominal segment with a transverse fold or carina near base and another near apex, the intermediate space very coarsely rugulose; pygidium oblong-oval, finely, longitudinally aciculated towards apex ........... Pycnothynnus, Ashm.

38. Metathorax obliquely truncate from the base, without a distinct metanotum .. . . . . . . . . . . . . . . . . .

Metathorax with a short but distinct metanotum, trapezoidal, the truncation abrupt, perpendicular; abdomen with a depression near apex and a delicate transverse carina just before apex; the depression finely coriaceous; second segment with a depression 
from the middile which is rugulose; pygidium oblong-oval, rugulose towards base; mandibles with a sinus before apex, appearing bidentate................... Anodontyra, Westwood.

39. Clypeus without a trace of a median carina, the anterior margin

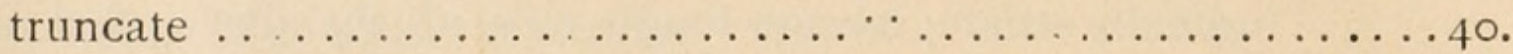

Clypeus with a more or less distinct median carina, the anterior margin subangularly produced.

Pygidium oblong-oval, longitudinally striate, and with a lobe or tooth on each side before the apex; first abdominal segment with traces of transverse carina or elevated lines at apex, the second segment with many transverse folds or carinæ, I 7 or more; metathorax sloping from its

base.................. Myrmecodes, Latreille (partim).

40. Pygidium oblong, with a more or less elongate, lanceolate elevation on its disk gradually broadened posteriorly, the elevation with some longitudinal lines towards base, smooth at apex; first abdominal segment with a depression at apex, the second segment with five transverse folds or carinæ, metathorax sloping from a little beyond its base, leaving a short but distinct

metanotum ................ Thynnoides, Guérin.

4I. Pygidium very narrow, or strongly compressed towards base, with an elevation towards apex $\ldots \ldots \ldots \ldots \ldots \ldots \ldots \ldots \ldots \ldots \ldots \ldots \ldots \ldots$.

Pygidium neither very narrow nor compressed towards base, without an elevation or disk, above flat or subconvex, striate, punctate or rugulose $\ldots \ldots \ldots \ldots \ldots \ldots \ldots \ldots \ldots \ldots \ldots \ldots \ldots \ldots \ldots \ldots \ldots \ldots \ldots \ldots \ldots \ldots$.

42. Head about twice as wide as thick antero-posteriorly, or three times as wide as thick when viewed from above.

Second dorsal abdominal segment with three or more transverse folds or carinæ .....................

Second dorsal segment with only one transverse carina just before apex, the anteriorly portion rudely

punctate. . ......... Psammothynnus, Ashm., gen. nov.

43. Second abdominal segment with many transverse folds or carinæ .44 . Second abdominal segment with three transverse folds or carinæ.

Pygidium elongate, smooth, the hypopygium with two converging carinæ at base ....................

(Type Thynnus carinatus, Smith.) 44. Second abdominal segment with 20 or more transverse carinæ, the first segment with a transverse furrow just before apex, the third and 
following segments smooth; head with a concave depression above each antenna that extends to the vertex; pygidium strongly compressed at the middle, and then broadened into an oval plate, the basal portion, which is separated from the oval apical portion by the strongly compressed portion, is transversely striated, while the apical portion is smooth............ Zaspilothynnus, Ashm.

Second abdominal segment with about I $_{3}$ or I $_{4}$ transverse carinæ, the first segment with many oblique striæ at the sides towards apex, the following segments after the second shining but microscopically shagreened, with a few scattered feeble punctures, especially noticeable on apex of the two last segments; pygidium compressed basally, dilated apically, but with an emargination on each side at apex, smooth and without transverse striæ at

base

Tachynomyia, Guérin.

45. Clypeus without a median ridge $\ldots \ldots \ldots \ldots \ldots \ldots \ldots \ldots \ldots$.

Clypeus with a median ridge.

Pygidium not very narrow, deflexed apically, longitudinally striated, and with a tooth or lobe at each side towards the base ; mandibles broad and flat, obtuse at apex, with a longitudinal grooved line along the inner margin and another along the outer margin for a little more than half

their length ................ Myrmecodes Latreille.

(Type Tiphia pedestris, Fabr.)

46. Head without convex impressions extending from the antennæ to vertex, subopaque; clypeus transversely narrowed, with a slight median tooth anteriorly; mandibles long, falcate; second dorsal abdominal segment with a transverse carina near base and another near apex, the intermediate space multistriated transversely; pygidium oblongoval, longitudinaily striated with a notch on each side before apex ; maxillary palpi 3 -jointed ; labial palpi 4-jointed .................. Hemithynnus, Ashmead.

Head with two convex impressions extending from the antennæ to the apex; clypeus transversely narrowed, with a slight median sinus anteriorly ; mandibles, falcate, acute; pygidium strongly compressed at sides just before the apex, then dilated, and as seen from behind appearing as an oval elevation more or less transversely aciculated, rarely smooth. Agriomyia, Guérin. 


\section{$2 \mathrm{BHL}$ Biodiversity Heritage Library}

Ashmead, William H. 1903. "CLASSIFICATION OF THE FOSSORIAL, PREDACEOUS AND PARASITIC WASPS, OR THE SUPERFAMILY VESPOIDEA." The Canadian entomologist 35, 95-107. https://doi.org/10.4039/ent3595-4.

View This Item Online: https://www.biodiversitylibrary.org/item/22193

DOI: https://doi.org/10.4039/ent3595-4

Permalink: https://www.biodiversitylibrary.org/partpdf/157310

\section{Holding Institution}

MBLWHOI Library

\section{Sponsored by}

MBLWHOI Library

\section{Copyright \& Reuse}

Copyright Status: NOT_IN_COPYRIGHT

This document was created from content at the Biodiversity Heritage Library, the world's largest open access digital library for biodiversity literature and archives. Visit BHL at https://www.biodiversitylibrary.org. 